\title{
BORIS SCHNAIDERMAN OU, DO SÉCULO E DA FERA
}

http://dx.doi.org/10.11606/issn.2237-1184.v0i26p68-83

Gutemberg Medeiros ${ }^{1}$

Pontifícia Universidade Católica (PUC-SP)

\section{RESUMO}

Este texto apresenta uma visão geral da vida e da atuação de Boris Schnaiderman como resultado preliminar de pesquisa em curso a partir de leitura de sua vasta obra em livros e jornais aliada a anos de convivência e recolha de depoimentos diretos. Pretende dar contribuição ao detalhar aspectos pouco conhecidos ou inéditos de sua trajetória para melhor entender a sua produção.

\section{ABSTRACT}

This text presents an overview of the life and performance of Boris Schnaiderman as a preliminary result of research in progress from reading his vast work in books and newspapers allied to the years of coexistence and collection of direct testimonies. It intends to contribute by detailing little or unknown aspects of its trajectory in order to better understand its production.

\section{PALAVRAS-CHAVE:}

Boris Schnaiderman; Memórias;

Literatura;

Jornalismo;

Cinema;

Fiodor Dostoievski.

\section{KEYWORDS:}

Boris Schnaiderman;

Memoirs;

Literature;

Journalism;

Cinema;

Fyodor Dostoyevsky.

\footnotetext{
${ }^{1}$ Gutemberg Medeiros é jornalista e pesquisador, Mestre e Doutor pela ECA/USP em Ciências da Comunicação e Pós-doutorando da PUC-SP em Comunicação e Semiótica.
} 
"Minha era, minha fera, quem ousa,

Olhando nos teus olhos, com sangue

Colar a coluna de tuas vértebras?

Com cimento de sangue - dois séculos -

Que jorra da garganta das coisas?

Treme o parasita, espinha langue, Filipenso no umbral de horas novas".

Óssip Mandelstam, 1923

Tradução de Haroldo de Campos

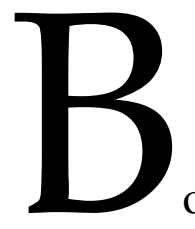

oris Schnaiderman estava especialmente envolvido com estes versos de Óssip Mandelstam em seus últimos dois anos, pelo menos. A ponto de se deixar, entre outros projetos, um livro de memórias intitulado "Meu século, minha fera" (na sua versão para o português). Estive com ele pela última vez em abril de 2016, em visita mais de cunho profissional, ao contrário dos frequentes encontros nos últimos 14 anos. Logo ao chegar, perguntei as novas e Boris contestou: "Tenho muito trabalho".

Não era apenas força de expressão. Além das memórias, pretendia fazer uma seleção de textos sobre literatura publicados em jornais e revistas e fechar uma coletânea de ensaios de Iúri Lótman em parceria com sua esposa (e colega e pesquisadora e interlocutora e muito mais) Jerusa Pires Ferreira. Outro trabalho que ficou apenas no projeto de refazer foi seu Leão Tolstói: antiarte e rebeldia que saiu pela Brasiliense, em 1983. Ele queria fazer algo maior do que essa breve publicação, somando muito material e reflexões realizadas desde então. Este texto foi somado à reedição de Khadji-Murát, em 2017.

Destes trabalhos, estava especialmente desgostoso com as memórias. Estava parado. Ao remexer no passado, vieram lembranças nada boas sobre algumas pessoas e ele não gostaria de escrever isso. Mas, ao mesmo tempo, sentia que a omissão seria um falseamento. Boris era assim. Se não podia falar bem, calava. Um exemplo aparentemente desimportante disso foi certa feita, quando estávamos falando sobre literatura e aludi ao francês Louis-Ferdinand Céline. Ele me cortou bruscamente e afirmou que nada teria a falar sobre ele. Percebi a minha gafe, afinal foi intenso colaborador dos nazistas durante a ocupação francesa, chegando a escrever obras de forte cunho antissemita. Logo, Boris não poderia ver algo de bom como expracinha da FEB que era. 
A primeira de suas feras não a reconheceu como tal. Ela passou-lhe ao largo como um sonho quando o menino de quase três anos de idade olha a mãe. Ela está com a porta aberta do apartamento esperando alguém. Entram dois rapazes com roupas muito diferentes e bonitas. Mas o que atrai o menino são as espadas. Ele brinca com eles de capa e espada. Apesar de mal poder levantá-la pelo peso. Diverte-se muito. Mas não deixam o menino pegar nas pistolas. Apenas tiram do coldre e as mostram, bonitas. Foram dias de muita brincadeira e diversão entre aqueles meninos, um pequeno e os dois grandes.

Odessa, 1921. Fim da Guerra Civil. Os rapazes são oficiais do Exército Vermelho. Os soviéticos acabaram de reconquistar essa estratégica cidade do Mar Negro, expulsando tropas francesas. O governo instruiu para as famílias da cidade portuária a hospedar soldados da guarnição. A família Schnaiderman recebeu esses dois jovens. Essas são as lembranças mais pregressas na vida do menino Boris. Quando adulto, lembrava e sorria. Foi maravilhoso.

Nada mais coerente girar suas memórias em torno de "Meu século, minha fera". Pois quase chegou aos 100 anos repletos de feras enfrentadas - de todas as proporções. Uma das últimas foi a plena indignação ante o que definia como "golpe de estado" na deposição da presidente Dilma Rousseff. Há anos tinha sérias reservas e críticas ao PT. Porém, mas uma vez falava o ex-pracinha que foi ter a Itália para tentar depor a ditadura aqui. Pois Boris era um democrata e defensor do estado de direito e das liberdades civis.

\section{Filho do Sputnik}

Nesse sentido, outra de suas feras deve ter sido no Curso de Russo na Universidade de São Paulo, iniciado por Boris em 1960. Não foi o primeiro em terceiro grau no país, mas o único que sobreviveu à ditadura iniciada em 1964. Para Boris, manter esse curso em pé ia além da docência: era um ato de desobediência civil visando manter o espaço de pluralidade de vozes ante o monólogo asfixiante do regime. Ele manteve esse espaço com a colaboração de seus amigos e alunos da universidade. Entre eles, o que havia de melhor na USP como Antonio Candido, Florestan Fernandes, Sérgio Buarque de Holanda e Paulo Emílio Sales Gomes.

O Curso de Russo foi aberto em função da ascendência da URSS como potência tecnológica na corrida espacial nos anos 50. O Curso foi filho do Sputnik. Tudo que era sobre a Rússia causava interesse no mundo, independente da coloração política. Inclusive gerando um boom de literatura russa também no Brasil. O que favoreceu Boris, ao iniciar a sua colaboração na imprensa em 1958 e publicar sua primeira tradução 
assinada com seu nome, coletânea de contos de Tchékhov. Entre 1944 até essa época, publicou traduções do russo de obras de Dostoiévski, Tolstói, Kúprin, Górki entre outros sob o pseudônimo de Boris Solomonov.

Boris não falava muito sobre si mesmo na ditadura de 1964 por alegar que nada tinha de relevante a declarar. Afinal, não sofrera o muito que tantos passaram. Falava coisas amenas como eventualmente ser chamado a "prestar esclarecimentos" e fases em que agentes à paisana que se julgavam disfarçados o seguiam na rua, geralmente de casa para a USP. Algumas vezes, sua casa foi invadida para revistas - naturalmente, sem ordem judicial - e verificavam cada livro da extensa biblioteca, folheavam para ver se havia alguma prova incriminadora e depois os jogavam ao chão. Ele apenas se dava ao trabalho de recolher todos e colocar de volta nos respectivos lugares.

Na sua trajetória, entrou no Partido Comunista em 1951 e saiu em 1956, muito devido à cruenta invasão da Hungria pelo Exército Vermelho. Outro motivo dos mais fortes foi discurso sobre os crimes de Stálin realizado a portas fechadas por Krushev em Congresso do Partido Comunista e não ventilado para a então URSS e tampouco a militantes de todo o mundo. Em paralelo a este silêncio, havia uma versão dessa comunicação cuja fonte era a CIA. Essa situação revoltava boa parte dos militantes que exigiam acesso ao que realmente foi a era stalinista. Segundo Boris, muita gente falava da cisão PCB que gerou a dissidência de 1958 e o PCdoB. Mas a grande evasão de quadros foi justamente em 1956, devido a estes dois fatores.

Em nosso último encontro, perguntei se ainda era comunista. Ele respondeu que sim, mas um comunista solitário - pois tudo o que foi tentado em torno de Marx não deu certo e há tempos não se filiava a partido algum. Mantinha vivo o sonho por uma sociedade mais justa e igualitária, muito diferente do que viu na ex-URSS.

\section{Swiss Films}

Sobre a importância de seus amigos da USP, sobre Paulo Emílio, Boris creditava a ele das maiores. Até conhecê-lo pessoalmente, não assistia a filme nacional. Dizia que tinha postura muito elitista ao não acreditar ser possível fazer cinema de qualidade aqui. Profundo conhecedor da tradição cinematográfica russa, muito além de Eisenstein, também admirava a produção europeia. Mas Paulo Emilio abriu seus olhos ao apontar-lhe, inclusive, o valor das produções da Atlântida e Vera Cruz, além do nascente Cinema Novo.

Carlos Calil, cineasta e ensaísta, cursou cinema na Escola de Comunicações e Artes da USP no início dos anos 70. Paulo Emílio Salles Gomes exibia clássicos do cinema em sua disciplina e, certo dia, Calil 
chegou atrasado justamente quando passou $O$ encouraçado Potemkin. Entrou na sala já escura e ouvia voz quase metálica a traduzir os letreiros em russo. Não era apenas tradução, havia interpretação, com modulações de voz sempre que necessário. Após o fim do filme, soube que a colaboração especial foi de Boris, a quem encontrou quando Paulo Emílio exibia outros filmes russos na Cinemateca Brasileira. Sempre com a mesma carga de interpretação com os letreiros, evidência de sua paixão pelo cinema.

A primeira vez que Boris foi ao cinema foi aos oito anos, 1925, em Odessa, ver fita muda norte-americana estrelada pelo cômico francês Max Linder. Imagino uma criança levada a determinado lugar sem ter noção do que era aquilo. Ele lembrava dessa experiência primeira, aos risos, "que sempre estava chovendo, fiquei muito admirado" - ou seja, as cópias eram de qualidade ruim. "Era tudo muito precário, e nos outros filmes parecia sempre estar chovendo dentro de casa".

Ele acreditava que esta foi a única vez que foi ao cinema ainda em Odessa. Mas ainda recorda de trailler de outro filme que chamou a sua atenção, cujo título era "Os diabinhos vermelhos", propaganda do Exército Vermelho da URSS. Outra coisa que o deixou admirado nessa primeira vez eram os cartazes de filme intitulado "Quem é o pai?". O garoto ficou "perplexo", como essa pergunta poderia existir? Isso sempre se sabia.

Logo que chegou ao Brasil, em 1925, era comum a família ir assistir filmes. Os Schnaiderman moravam na Rua Teodoro Sampaio, perto do largo de Pinheiros, em São Paulo, e frequententavam um dos extintos cinemas de bairro da época perto de casa. Sempre aos domingos. O que chamava a sua atenção era a "plateia sempre cheia de namorados". $\mathrm{Na}$ década de 30, as idas ao cinema eram rareadas "sempre por falta de dinheiro". Logo, em sua formação, o cinema não exerceu um papel dos mais importantes.

Um de seus maiores envolvimentos com o mundo do cinema foi quando seu pai, Solomon Schnaiderman, se associou a uma distribuidora de cinema Swiss Films e a especializou como talvez a primeira dedicada a trazer dilmes russos ao Brasil. Entre os filmes projetados, esteve a primeira parte de Ivan, o terrível, de Eisenstein. Boris achava interessante observar que os filmes soviéticos continuaram a ser exibidos mesmo depois do fim das relações diplomáticas entre Brasil e URSS, em 1947. Mas isso durou apenas alguns meses até a proibição de circulação desses filmes pelo governo brasileiro, determinante para o fim da empresa de Solomon. Apesar do empresário também trazer filmes de outras nacionalidades, como os italianos de Vittorio De Sica do tempo do fascismo.

Primeiro Boris cuidou, com o pai, da sede carioca da Swiss Films e chegou a abrir filial em São Paulo. Entre os filmes que ele mesmo respondeu pela distribuição está $A$ flor de pedra do diretor Alexander 
Ptushko (1900-1973), com muito sucesso de público por ser o primeiro russo completamente a cores depois da segunda parte de Ivan, o terrível de Eisenstein. A primeira parte de Ivan, o terrível foi fracasso de bilheteria. $\mathrm{O}$ público reagiu mal, pois estava acostumado com os filmes americanos. $\mathrm{O}$ filme russo era considerado muito lento. "Eu me lembro de alguém sair do cinema xingando: 'terrível é o filme, e não o Ivan'”, entre risos.

Porém, a crítica falava muito bem de todos os filmes soviéticos, só elogios, especialmente ao Ivan. Com esse sucesso de divulgação, havia sucesso de público na estreia. A partir da segunda exibição, as salas ficavam vazias. A distribuidora não conseguia entrar nos grandes cinemas, apenas nos de médio porte. Mas um dos filmes das vanguardas russas que mais o tocou foi Um homem com uma câmera de Dziga Vertov. Pelas muitas cenas filmadas pelas ruas de Odessa, em 1929, traz a cidade tal qual ele guardou na memória de sua infância.

\section{Jornalista da Tass}

Uma das obras em que Boris melhor soube harmonizar passagens de sua vida para ilustrar determinadas realidades a expressar está em seu volume de ensaios Tradução: um ato desmedido (Perspectiva) e infelizmente pouco divulgado na imprensa quando de seu lançamento em 2011. Lá narra como se deu seu envolvimento com a língua russa nem sempre como tradutor para discutir aspectos vários seja sobre tradução ou elementos de uma visão de mundo das mais ricas compartilhadas com o leitor.

Como é normal, nem sempre ele tinha a dimensão exata do que viveu. Isso se tornou evidente quando conta dos meses em que foi "secretário" - assim se predica - do correspondentre da Agência Telegráfica da URSS, mas conhecida como Tass, entre 1945 e 1946. Ao ler a descrição, como jornalista não pude concordar com aquilo e fui falar-lhe para eliminar essa dúvida. Pessoalmente, manteve semelhante versão reiteradamente. Então, pedi para descrever seu cotidiano como "secretário" do correspondente. Boris chegava ao hotel onde o russo estava hospedado, os funcionários de atendimento já tinham em mãos os jornais e as revistas não vistos ainda pelo hóspede estrangeiro. Boris recolhia os exemplares e os lia por completo para recolher as notícias que poderiam atender aos interesses de leitores da Tass. Feita a triagem, ainda seguindo o relato de Boris, ia ao encontro de Iúri Kalúguin e lia em russo o que estava em português. Quando se interessava por alguma notícia, pedia para Boris relê-la devagar e tomava notas. Logo depois, o jornalista escrevia a matéria em russo para Boris ler. Além de revisar os dados, eventualmente o "secretário" somava ao texto algum dado que, originalmente, estivesse em pressuposição em relaçao ao leitor brasileiro, mas não ao russo. 
Como lembrava Paulo Rónai na primeira vez que se pôs a traduzir literatura brasileira, ainda em Budapeste, para os dicionários de Português de Portugal o termo "morro" era apenas um acidente geográfico. Mas, pelo texto brasileiro, parecia ter outro sentido não compreendido e só pôde entendê-lo quando chegou ao Rio de Janeiro.

Após a definição de quais sugestões de Boris seriam aceitas, providenciava-se o texto final ainda com uma última leitura deste. Baseado em seu depoimento, constatei cinco determinadas atividades exercidas por jornalista: pré-pauta (quando o tema da matéria é selecionado), pauta (quando o tema é definido), produção (onde detalhes além da pauta são somados à reportagem ou à matéria), subedição (definição do texto ainda com mudanças) e edição final da matéria.

Isso para não falar de um texto preocupado de ser o mais direto e simples possível, dosando um estilo dos mais apurados, como já era uma preocupação de Boris e presente em toda a sua produção posterior. Ele lembrava que chegava a ser difícil trabalhar com Kalúguin. Especialmente quando queria convencê-lo da importância de determinadas notícias para o público da Tass e o correspondente teimava que não - problemas atinentes à pré-pauta e pauta.

Ele era um típico funcionário da era estalinista, recordava Boris, pois só fazia o estritamente essencial para receber o seu salário. Em décadas conhecendo estrangeiros vindos ao Brasil, o russo foi excessão à regra ao não demonstrar interesse pela cultura nacional e tampouco em relação à exuberante natureza, tão diversa da Rússia. "Não se familiarizou com a cultura brasileira, não procurou se informar". Depois virou tradutor e era o tradutor de Jorge Amado com certa habilidade na Rússia.

A única vez que Kalúguin realmente se interessou em sair e ver algo foi o carnaval de 1946, o qual ficou maravilhado. Resultado: escreveu laudas e laudas de texto completamente irrelevante para a Tass. Boris tentou alertá-lo para não enviar o material, sem sucesso. Pelo que soube, nada foi aproveitado. Boris conheceu Kalúguin em 1945, então era funcionário do Ministério da Agricultura e "estava louco para largar esse serviço". Como Boris foi alfabetizado em russo em Odessa, com cartilhas ornadas com retratos de Lênin, foi contratado e trabalhava com outro brasileiro. "Ele acabou sobrando, já que só eu conseguia fazer o resumo das notícias em russo".

\section{"Pessoas cultas: precisa-se"}

Talvez um dos ofícios menos conhecidos já exercidos por Boris tenha sido na década de 1950, por mais de cinco anos. Depois de dirigir o núcleo de agricultura da Escola Agrotécnica de Barbacena, entre 1948 e 1953, voltou desempregado para São Paulo. “Na ocasião já tinha constituído 
família. Uma vez, eu abri o jornal O Estado de S. Paulo e vi um anúncio em letras quase garrafais: 'Pessoas cultas: precisa-se'. O reclame dizia: 'Precisase de pessoas que saibam inglês e francês, é desejável também o conhecimento de italiano, latim, grego'. Eu estava desempregado, arrisquei e fui."

No anúncio de classificados, nada mais de informação além do endereço ao interessado se dirigir. Nenhuma pista a revelar a função. Boris foi e deu com a Editora Jackson que, posteriormente passou a se chamar Mérito.

Queriam fazer uma enciclopédia, então eles estavam convocando pessoas. Eu e mais um candidato, éramos os dois que fomos aprovados e ficamos trabalhando lá. Aquilo era uma instituição muito estranha que devia dar um prejuízo terrível aos americanos por causa do sistema todo, era uma coisa muito complicada. Eles resolveram simplificar. De vez em quando vinha o representante da Jackson, um colombiano, para controlar. Mas a coisa era completamente doida, completamente estúpida. Uma porção de gente trabalhando, outros controlando. E os que controlavam, às vezes, sabiam menos do que aqueles que estavam redigindo os verbetes, era uma confusão terrível.

Boris passou a escrever os verbetes sozinhos até terminar a empreitada. A Enciclopédia Brasileira Mérito (há edições em bibliotecas da USP) contabiliza 14.516 páginas em 20 volumes. Sem menção ao verdadeiro autor. É nítido ao leitor como os verbetes são compostos em textos informativos, mas com certa leveza ensaística que torna a leitura das mais agradáveis. Destaque especial fica para os verbetes sobre escritores de língua russa. Jerusa Pires Ferreira defende ser esse ofício de muita importância na vida de Boris. Ela afirma que conquistou um vasto conhecimento geral nada reducionista, determinante para a sua futura atuação como professor, pesquisador e orientador de trabalhos de Graduação e de Pós-Graduação na Universidade de São Paulo (USP). Realmente, era difícil encontrar tema sobre o qual Boris não tivesse, pelo menos, alguma noção.

\section{Ofício pelo riso}

Hilda Hilst, em 1987, esteve envolvida em produção literária cuja uma das principais tônicas era o riso. Na época, ela gostava de lembrar passagem escrita por Elias Canetti, quando afirmava que gostaria mesmo era de ingerir o outro. Dada a impossibilidade de fazê-lo, apenas ria. Pois os movimentos peristálticos do riso e da deglutição são simplesmente os mesmos. 
Em ambos os casos, a ferramenta primeira são os dentes. Rir é uma forma de alteridade, de buscar e compreender e metabolizar o inteiramente outro. Pelo riso amealha-se o discurso do outro, a sua essência pelo verbal ou não verbal, para transformá-lo no que é seu redimensionado em reflexão. $\mathrm{O}$ riso como versão, diversão, reversão, subversão.

A aventura do riso, em várias frequências, está presente em toda a obra de Boris. Pela fina ironia ou humor sutil em seus ensaios até nas opções de suas traduções. Basta lembrar o conto do fazedor de caixões de Aleksander Púchkin até devastar a visão equivocada de um Dostoiévski exclusivamente soturno, especialmente nos contos "O crocodilo" e "O Senhor Prokhartchin".

Dostoiévski escreveu este último quando tinha apenas 25 anos e considerado até recentemente como obra imatura. Não apenas traduziu esse conto, mas o publicou no volume Dostoiérski Prosa Poesia, infelizmente há anos fora de catálogo. Boris mesmo reconhecia como o humor é um elemento importante em toda a sua produção. Especialmente ao narrar situações de conflito, aí é onde o humor mais aparece. Ainda quanto ao riso, inevitável retomar como Boris foi o introdutor da obra de Mikhail Bakhtin no Brasil, pelos cursos e orientações na USP e em artigos publicados ao longo de anos e enfeixados na infelizmente também esgotada coletânea Turbilhão e semente.

Contudo, Jerusa Pires Ferreira adverte que o riso na obra de Boris é de outra natureza da de Bakhtin, pois este trabalhou mais o riso de ordem intelectual em resposta à repressão dos anos stalinistas. $\mathrm{O}$ riso é uma constante também pelo senso de humor de Boris, que emerge do silêncio quando menos se espera, de "derrubar quarteirão", brinca Jerusa. Por exemplo, o riso inesperado surge quando ele respondia quais os três autores russos que pouco foram traduzidos no Brasil e bem o merecem: Mikhail Saltikóv-Shchedrin (1826-1889), Mikhail Zóschenko (1895-1958) e Andrei Platônov (1889-1951). Justamente três grandes satíricos. Mesmo Zóschenko empunhando, muitas vezes, o riso melancólico, humor triste. Ele destacava Platônov por sua vasta obra publicada mal na ex-URSS, omitindo as menos violentas.

Por outro lado, algo aparentemente desimportante, mas que apagava o riso em Boris era o da sua identidade. Ficava muito chateado com a recorrência que jornalistas cometiam ao identificá-lo como "ucraniano" por ter nascido na Ucrânia. Em suas próprias palavras:

Eu vim em fim de 1925. Portanto, com oito anos de idade. Agora, o senhor frisou que eu nasci na Ucrânia. Está certo. Mas eu sou de formação russa. Vivi em Odessa que, pelo menos naquela época, era uma cidade exclusivamente russa. Ucraniano eu só ouvia quando ia à feira. Assim, pessoas que vinham do campo comercializar seus produtos falavam 
ucraniano entre si. Mas, em volta de mim, só se falava russo. Eu fui alfabetizado em russo, frequentei escola primária em russo.

A vinda dos Schnaiderman ao Brasil tem certo aspecto ímpar. O último pede para sair da URSS foi em 1923, onde se liberou a emigração. Após, o normal era a imigração clandestina, como refugiados. Assim veio a família de Tatiana Belinky, nascida em Petrogrado (atual São Petersburgo), em 1919, mas a família veio de Riga (Letônia) em 1929).

Boris contava que seu pai, Solomon, decidiu emigrar por alguns motivos dos mais sólidos. Primeiro, era judeu assimilado (já desligado das tradições religiosas). "Eu ouvia meus pais falando com minha avó numa língua completamente desconhecida e, anos depois, soube que era ídiche, que nunca aprendi". Mas a marca judaica não se apagava do passaporte interno. $\mathrm{O}$ antissemitismo do czarismo foi mantido na URSS. Solomon queria que seus filhos, Boris e Berta, tivessem plena liberdade de cursarem o terceiro grau na carreira que escolhessem e vários cursos eram vedados a judeus. Além disso, Solomon era comerciante. "Inclusive nós viemos ao Brasil porque, como comerciante, ele não estava se adaptando ao sistema comunista. Viemos por causa disso. Não por razões políticas. Mas ele não conseguia se adaptar ao sistema.", afirmava Boris.

Mesmo assim, sair legalmente não foi fácil. Boris, sem entrar em detalhes, expunha que seu pai tinha boas relações com as autoridades soviéticas da época em Odessa e conseguiu os passaportes e demais documentos necessários para emigrar. Todos eles foram exterminados 10 anos depois com os expurgos estalinistas, pontuava Boris. A decisão de vir ao Brasil foi por facilidades de conseguir visa de entrada, já que tinham um primo residente em São Paulo, aonde logo vieram.

Uma das primeiras coisas que Boris sentiu falta ao chegar aos oito anos foi o mar, já que Odessa era uma cidade portuária. $O$ que eventualmente era amenizado com idas a Santos, apesar do mar de Odessa de intenso azul ser diferente do cinza chumbo da baía quase fechada de Santos, mas já era um alento ao menino. Dessa primeira vinda restam fotos de Boris e Berta em frente ao então Parque Balneário Hotel e Cassino em frente à praia do Gonzaga. Lá se vê o rapaz de calças curtas e boina. Boinas que ele manteve ao longo da vida e dificilmente saía com a cabeça descoberta.

Outro estranhamento foi a falta de calefação nas casas paulistanas, onde realmente se fazia frio - apesar de bem diferente do inverno do hemisfério norte. Boris complementava que ouviu o mesmo tipo de surpresa de estrangeiros ao longo das décadas.

Imagino uma criança de oito anos desembarcar em um país tropical vindo de clima temperado só conhecendo o idioma russo. Os pais, Solomon e Elisa, conseguiam se comunicar em francês. Porém, Boris 
garantia que não sentiu trauma algum. Afinal, moleques não precisam de idioma para se comunicar - jogos e demais brincadeiras logo sanam essa comunicação mediata. Mas demorou alguns meses em sala de aula em colégio estadual para Boris começar a compreender a língua portuguesa. $\mathrm{O}$ mesmo não aconteceu com a sua irmã Berta, com 12 anos de idade. No primeiro dia de aula voltou para casa em choro convulso determinada a não sair mais de casa. Não gostava de nada ali e nada entendia do que lhe falavam. A solução encontrada pelos pais foi contratar uma preceptora russa que lhe ensinou as disciplinas básicas e a língua portuguesa. Em um ano, Berta voltou aos bancos escolares e depois fez carreira bem-sucedida como arquiteta no Rio de Janeiro.

\section{No princípio, não era Gorki}

O escritor Vladimir Nabokov definiu que, para o bem e para o mal, a Rússia legou ao Ocidente dois termos: progrom e intelingentsia. $\mathrm{O}$ primeiro era a atividade nacional de extermínio sistemático a judeus sem qualquer interferência do Estado. $\mathrm{O}$ segundo envolvia os que estavam dedicados a pensar a sua realidade - não apenas artistas, professores, acadêmicos, escritores e jornalistas, os produtores de textos, mas envolvia os leitores também. Os Schnaiderman, nesse sentido, eram intelectuais, pois trouxeram na bagagem obras literárias, eram letrados. E mantinham contato com outros emigrados russos que intercambiavam livros em cirílico ou importavam, geralmente publicados em Riga ou Berlim. Boris era um leitor apaixonado desde a infância.

Assim como outros imigrantes europeus e do mundo árabe, Solomonon e Elisa tiveram como regra básica o de sacrifício de uma geração. Fazer o possível, passando privações severas, para que os filhos tivessem a melhor formação possível e se tornassem universitários e membros bem-sucedidos da classe média. O mesmo aconteceu com Boris e Berta que frequentaram os melhores e mais caros colégios particulares. Boris queria ser tradutor e estudar literatura, mas seu pai o advertia de que isso não dava camisa. Logo, pressionado cursou Agronomia.

Porém, não pode exercer por não estar ainda naturalizado, exigência do Estado Novo getulista. Tinha casa e comida garantidos na casa paterna, então começou a dar aulas particulares e pensou em traduzir do russo. Desde o começo da Segunda Guerra, explodiu a procura de literatura russa no Brasil. O que também era uma forma de praticar oposição ao regime vigente. Boris tomou coragem e procurou uma das mais importantes editoras cariocas da época, a Vecchi, que também apostava neste segmento de mercado.

Ele tomou coragem e procurou a casa publicadora com o projeto de traduzir a trilogia autobiográfica do autor russo de sua maior predileção 
na época Máximo Gorki: Infância, Ganhando meu pão e Minhas Universidades. A editora já tinha em catálogo alguns títulos desse autor, mas a prioridade do momento era o de lançar a primeira edição integral de Os irmãos Karamazov, de Dostoiévski, e ofereceram uma edição espanhola para Boris realizar o trabalho. Ele alegou que não faria do espanhol, mas do russo. $\mathrm{O}$ editor aceitou o trabalho e o tradutor iniciante caiu em si na calçada da casa publicadora (Rua do Resende, no. 144, na Lapa). Nunca lera uma obra de Dostoiévski e tinha de achar uma edição em russo.

Percorreu a colônia russa carioca até descobrir um exemplar, $\mathrm{O}$ único dicionário de russo na então capital federal era na Biblioteca Nacional e para a língua francesa. Então, para fazer o extenso trabalho, elencava lista de palavras, pegava o bonde para a Cinelândia e lá consultava, eventualmente conferindo o dicionário francês-português. Assim, nas condições mais precárias, fez a versão e entregou a Vecchi. Como tinha certeza de ser um resultado com deficiências, negociou publicar com o pseudônimo Boris Solomonov - cortava a terminação de seu patronímico Solomonovitch e criava um código para depois, se quisesse, resgatar a autoria.

Após entregar a tradução, alistou-se como pracinha da FEB. Voltou logo com o fim da guerra, em 1945, e foi no centro do Rio de Janeiro. Viu em todas as livrarias a edição dos Karamazov em destaque e os livreiros informavam ser um sucesso de vendas. Na sua ausência em fevereiro de 1944, a Vecchi fez ampla campanha publicitária do lançamento nos principais jornais cariocas. $\mathrm{O}$ anúncio já abre com a exclamação: "O acontecimento literário do ano!" em letras todas em maiúsculas e em negrito. Para informar ser a primeira tradução do original no Brasil e com texto integral, em "esmerada versão de BORIS SOLOMONOV" devidamente acompanhado com reprodução da capa.

O destaque de tradução original não era gratuito, pois não havia mão de obra qualificada no país para essa empreitada. A ampla publicação de obras russas era vertida de segunda língua - geralmente do francês - e por vezes, nem trazia o nome do tradutor. Sem entrar em números, Boris dizia que viveu as condições do tradutor da época. Recebia muito pouco pela versão e mais nada, o texto passava a ser propriedade da editora. Apesar da autocrítica de Boris, não poucas vezes Paulo Bezerra afirmou que a versão de Karamazov de Boris é muito boa, tendo aproveitado algumas soluções para a sua própria editada pela 34 .

Boris publicou outros trabalhos como Solomonov para a Vecchi e outras chancelas. De Górki, fez a quatro mãos com Galvão de Queiroz o romance Os Artamonov. Até onde cheguei em minhas pesquisas, este romance de Górki, os Karamazov e Yama de Kúprin foram as obras que Boris não retomou e publicou com seu próprio nome posteriormente. 


\section{Muito além da sala de aula}

Assim como o Curso de Russo da USP. Pode-se dizer que a trajetória intelectual de Boris passou a ser conhecida por público mais amplo e alavancou as outras etapas de sua vida são filhas do Sputnik. Em 1953 acontece uma iniciativa que marcou a história do jornalismo brasileiro, a abertura do "Suplemento Literário" de O Estado de S. Paulo concebido por Antonio Candido e Décio de Almeida Prado. Ali se concentravam colabores fixos e eventuais do melhor da intelectualidade brasileira da época a escrever ensaios verticais sobre os mais variados temas em torno de manifestações artísticas. Dado o grande interesse em torno da literatura e cultura russas resultante do avanço tecnológico soviético, Boris foi convidado a escrever sobre o tema em completa liberdade.

$\mathrm{Na}$ primeira fase do suplemento semanal editado por Almeida Prado, de 1956 a 1967, Boris publicou 66 textos, sendo 21 sob a nomeação "Letras Russas". A exemplo de sua colaboração para a TASS, ele manteve o tino jornalístico apurado, pois dedica os dois primeiros textos ao "caso Pasternak". O primeiro texto, de 15/11/1958 e intitulado "O russo Boris Pasternak" é escrito sob uma maré de detratores do autor russo entre críticos da URSS, europeus e mesmo das Américas devido à publicação do romance Doutor Jivago. Pasternak tentou publicá-lo na Rússia, mas foi recusado pela revista literária Novy Mir e pela editora estatal. O autor contrabandeou a obra pelo editor Giangia como Feltrinelli, um dos mais importantes na Itália e membro do Partido Comunista Italiano, e o publicou em 1957. Logo após, foi escolhido para o Prêmio Nobel nitidamente sendo visto pela organização como uma espécie de autor dissidente. $\mathrm{O}$ governo soviético permitiu a sua saída para receber a homenagem, com a condição de não poder voltar. Pasternak decidiu ficar, pois não conseguiria ficar exilado da língua russa.

Ao longo de 1858, foi o assunto do momento em revistas e jornais. Boris inicia a sua contribuição justamente com texto explicitando a importância do autor para a literatura russa contemporânea sem citar uma vez sequer o romance. "O grande Pasternak, tão vilipendiado em seu país, também tem sido incompreendido no exterior, pelo menos no que há nele de mais tipicamente russo, de mais genuinamente humano, no seu modo de sentir a Rússia, de se considerar indissoluvelmente ligado à sua terra a ponto de não admitir a hipótese de recomeçar a vida no exterior", é o período que abre o ensaio jornalístico.

Sem citar o nome do romance, Boris urde toda uma argumentação em polêmica velada em relação ao momento. Na sequência, em 27/12/1958, Boris publica "Ainda Boris Pasternak". Ele inicia o texto afirmando o quanto é difícil uma apreciação crítica de Doutor Jivago (sai da polêmica velada para a explícita) dado o perigo "de se viciarem pelo clima 
que se criou em torno de sua pessoa e pela simpatia ou antipatia despertadas por suas ideias" expressas no romance. Evolui o texto detalhando aspectos da obra poética de Pasternak que se desdobra em sua prosa, inclusive no personagem Jivago, igualmente poeta. Boris destaca visões torturadas da existência emanadas da prosa do autor, Relato (1934), "fortemente marcado pela influência de Dostoiévski".

Apesar da dificuldade de apreciar Jivago, Boris aponta a força desse romance. "As pequenas coisas da vida de um homem adquirem ali uma intensidade e vida peculiares. $\mathrm{E}$ as suas ideias passam também a viver, como nos romances russos do século XIX". O crítico aponta a amargura que Jivago destila sobre os acontecimentos revolucionários, mas não raro na literatura sobre o período, como em O beco de Moscou de Ilia Ehrenburg. Mas com a diferença que Pasternak deixa clara as posições de Jivago como "revoltado permanente" e de si próprio enquanto antimarxista, antimaterialista e avesso a qualquer compromisso com o espírito da época.

O jornalismo cultura de Boris seguiu-se apresentando e detalhando sobre a produção de outros autores russos: Isaac Bábel, Tchékhov, Gógol, Dostoiévski, Tolstoi, Ehrenburg, Púshkin, MarinaTzvietáieva, Constantin Pautóvski, Leonid Andréiev, entre tantos outros. E sobre Maiakóvski e poesia russa, prenunciando os trabalhos de coletânea do primeiro e a Poesia russa moderna que viram posteriormente a quatro mãos com Haroldo e Augusto de Campos. Ou ainda "Maiakóvski e o cinema" (08/03/1961) em que descreve várias formas de relacionamento do poeta com a sétima arte - de argumentos a ensaios. A semente de trabalho mais amplo, A poética de Maiakovski (Perspectiva), originalmente sua tese de doutorado (USP, 1970), cuja banca foi formada por Antonio Candido (orientador), Adolfo Casais Monteiro, Alfredo Bosi e Sérgio Buarque de Holanda. Outro texto que prenuncia trabalho futuro é o ensaio "Materiais sôbre Dostoiévski" (17/12/1960) a respeito de recente publicação russa de resenha dos documentos sobre o escritor de autoria de Leonid Grossman nas "Obras reunidas" de Dostoiévski (1956=58). Boris descreve essa produção e conclui "que não traz a marca de repetição ou de rotina, mas de uma pesquisa habilmente conduzida e apresentada". Boris publicaria a coletânea de Grossman Dostoiévski, artista pela Civilização Brasileira (1968), infelizmente ainda fora de catálogo. Não poucas vezes, falamos sobre esta produção pela qual Boris manteve viva admiração sempre, pois não envelheceu. Sendo pertinente até hoje tanto para os que se iniciam neste universo quanto para leitores já elaborados.

Talvez o primeiro ensaio no Brasil a explicar uma das vertentes mais importantes dos estudos da linguagem do século passado foi o nomeado "Frutos do "método formal"" (03/03/1962). Apesar das severas críticas que ainda sofria na URSS, Boris revela a influência de seus vários críticos literários e de como o grande destaque em estudos no Ocidente, a exemplo 
da canônica obra Russian Formalism de Victor Erlich. Boris detalha aspectos dessa produção como as contribuições de Jakobson, Eichenbaum e Chklóvski. No encadeamento de posicionamentos, Boris alude mesmo ao anteriormente abordado Grossman e seus estudos sobre Dostoiévski e em "exemplos característicos de aproveitamento inteligente de processos desenvolvidos pelos formalistas russos", chega, por este crítico, a citar também, provavelmente pela primeira vez no Brasil, Mikhail Bakhtin e sua contribuição com a ideia do romance polifônico. O mesmo Bakhtin que Boris introduz aqui nos estudos literários e orientações de trabalhos acadêmicos na USP e PUC-SP a partir de Dostoevskij: poética e estilística (Rinaudi, 1968), primeira edição fora da Rússia de Problemas da poética de Dostoiévski.

Muito ainda há o que se descobrir nessa ampla produção jornalística de Boris que avançou em outros jornais e revistas até poucos anos de seu falecimento. Cabe ainda uma ressalva importante: essa produção colaborou decisivamente para formação de público leitor de literatura e cultura russa, dado ser o Suplemento Literário uma referência não apenas no estado de São Paulo, mas comentado por outros jornais e revistas em todo o país. Ou seja, uma verdadeira atividade de docência que foi muito além da sala de aula. Este rico material ainda foi laboratório de Boris para aulas na USP e PUC-SP, além de suas publicações em livro. Material este que aguarda reedição em coletâneas em livro para continuar o seu papel em formar novos leitores.

\section{Casa Civil}

Para falar de Boris, impossível esquecer a importância da pesquisadora e professora da PUC-SP Jerusa Pires Ferreira. Dizer que foi sua segunda esposa com quem construiu cumplicidade e afetividade únicas não é o bastante. Ela primeiro o conheceu como pesquisadora no final dos anos 70, para dialogar sobre a vertente de pensamento Semiótica de Tártu-Moscou, quase desconhecida no Brasil e que Boris também introduziu aqui. O companheirismo entre pesquisadores refluiu em profunda amizade para, depois, resultar em relacionamento pleno. Com interesses em comum, mas em plena independência intelectual, se auxiliaram mutuamente em suas respectivas criações. Quando Boris falava de Jerusa, recorrência, não escondia a sua admiração intelectual pela companheira e o quanto ela o auxiliou em reflexões e até em sugerir soluções para traduções. Incluindo até trabalhos a quatro mãos, como a publicação Geunádi Aigui: silêncio e clamor (Perspectiva) em trabalho conjunto do casal em traduções e ensaios sobre o poeta.

Vida e obra de Boris não cabem em poucas palavras, muito de sua produção ainda está por ser descoberta. Porém, pista das mais valiosas 
ouvi de Jacó Guinsburg, fundador da Editora Perspectiva com títulos de Boris em catálogo: "Na República Boris Schnaiderman, o Ministério da Guerra é Estruturalista, mas a Casa Civil é Bakhtin".

Rigor e diálogo em constante busca do inteiramente outro. Assim era e continua sendo esse rapaz russo que veio de Odessa que enfrentou várias feras ao longo de 99 anos. 